J. Ris. \& Ap. Mat. Vol. 03 No. 02 (2019) pp. 78-88

Jurnal Riset dan Aplikasi Matematika

e-ISSN: 2581-0154

URL: journal.unesa.ac.id/index.php/jram

\title{
PENJADWALAN PROYEK PERUMAHAN DENGAN OPTIMASI WAKTU DAN BIAYA HARIAN
}

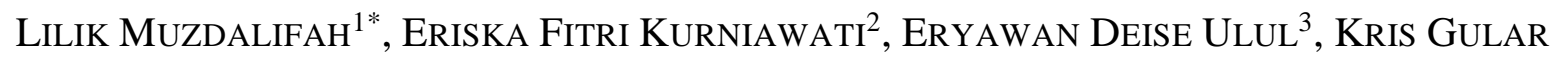 \\ PAMITRA $^{4}$ \\ 1,2,3,4Program Studi Matematika, FMIPA, Universitas PGRI Ronggolawe Tuban \\ *muzdalifahlilik@gmail.com
}

\begin{abstract}
ABSTRAK
Penjadwalan proyek yang efektif dan realistis adalah penjadwalan sistematis yang terintegrasi dengan berbagai komponen proyek, yaitu waktu, sumber daya, dan biaya proyek. Penelitian ini bertujuan untuk mengembangkan penjadwalan proyek yang realistis dengan mengintegrasikan dua komponen proyek, yaitu optimasi waktu dan biaya harian. Biaya harian dikatakan optimal ketika rata-rata penyimpangan biaya harian terhadap rata-rata biaya perhari adalah minimal. Penelitian ini menggunakan metode CPMCS yang merupakan kombinasi dari metode Critical Path Method (CPM) dan Cuckoo Search (CS). Hasil penjadwalan dengan CPM digunakan sebagai batasan waktu pengerjaan proyek pada algoritma CS. Metode ini diterapkan pada proyek pembangunan perumahan dua lantai tipe 65. Hasil penelitian menunjukkan bahwa penjadwalan proyek dapat dibuat dengan mengoptimalkan waktu dan biaya harian sekaligus tanpa keluar dari batasan waktu optimal pengerjaan proyek. Nilai optimum yang didapatkan berupa rata-rata penyimpangan biaya harian, yaitu sebesar 712510. Nilai tersebut lebih minimal dibandingkan dengan pengerjaan menggunakan metode CPM (Earliest), CPM (Latest), maupun CPMGA.
\end{abstract}

Kata Kunci: Penjadwalan Proyek, CPM, Cuckoo Search

\begin{abstract}
The effective and realistic project scheduling is a sistematically schedule that integrated with various of project components, that are time, resource, and cost of project. This research aimed to develop realistic project scheduling by integrating two components of project, that are optimization of time and daily cost. Daily cost is said to be optimal when the rate of absolute difference to its daily rate is minimal. This research use CPM-CS method that is the combination of Critical Path Method (CPM) dan Cuckoo Search (CS). The result of CPM is used to be the range of project time in CS algorithm. It is applied to the 65 type of two-storey residential development project. The results of the research show that the project scheduling can be made by optimizing time and daily costs at once without out of the range of optimal project time. The optimal value is the rate of daily differences, that is 712510 . This value is minimal than CPM (Earliest), CPM (Latest), and CPM-GA.
\end{abstract}

Keywords: Project Scheduling, CPM, Cuckoo Search 


\section{Pendahuluan}

Penjadwalan proyek merupakan kegiatan merencanakan waktu pengerjaan proyek mulai dari identifikasi jenis kegiatan, keterurutan, sampai kurun waktu (durasi) yang dibutuhkan setiap kegiatan. Dalam pelaksanaannya, proyek seringkali mengalami keterlambatan dikarenakan penjadwalan yang kurang optimal [1]. Selama ini, penjadwalan proyek banyak dibuat dengan hanya berorientasi pada waktu pengerjaan proyek tanpa memperhatikan faktorfaktor lain yang berpengaruh. Metode yang sering digunakan adalah Critical Path Method (CPM) dan Program Evaluation and Review Technique (PERT) [2,3,4].

Untuk meminimalkan keterlambatan proyek, penjadwalan proyek harus dibuat lebih efektif dan realistis, yaitu penjadwalan sistematis yang terintegrasi dengan berbagai komponen proyek, seperti waktu, sumber daya, dan biaya proyek. Biaya proyek bersifat penting dan sensitif dalam suatu perencanaan proyek. Penjadwalan proyek yang kurang tepat dapat mengakibatkan biaya proyek meningkat. Kelonggaran waktu (slack) pada durasi proyek yang kurang efektif juga dapat menimbulkan penyimpangan biaya. Arifudin [5], Junaidi [6], Andriani [7], Sediyanto [8], telah berhasil menganalisis performa waktu dan biaya proyek sekaligus dalam penjadwalan proyek. Pada penelitiannya, Arifudin menggunakan metode CPM yang dikombinasikan dengan Genetic Algorithm (GA) untuk menyelesaikan masalah penjadwalan proyek dengan meninimalkan penyimpangan biaya harian dan diaplikasikan pada data simulasi. Dalam konteks masalah yang sama, Muzdalifah [9] juga mengembangkan metode CPM yang dikombinasikan dengan Cuckoo Search (CS). Hasil penelitian menunjukkan bahwa CPM-CS menghasilkan waktu dan rata-rata penyimpangan yang lebih optimal dibandingkan dengan CPM (Earliest), CPM (Latest), maupun CPM-GA.

Proyek perumahan di Kabupaten Tuban berkembang dengan pesat. Penjadwalan proyek perumahan selama ini dilakukan berdasarkan pengalaman pelaksanaan proyek sebelumnya dan belum memperhatiakan optimasi biaya harian proyek. Berdasarkan permasalahan tersebut, peneliti akan menganalisis performa CPM-CS secara riil pada masalah penjadwalan proyek perumahan dengan mengoptimalkan waktu dan biaya harian. Penjadwalan tersebut diharapkan dapat menjadi solusi bagi permasalahan penjadwalan proyek yang ada di lapangan.

\section{Tinjauan Pustaka}

\subsection{Penjadwalan Proyek}

Proyek didefinisikan sebagai himpunan kegiatan yang saling terkait dimana masingmasing kegiatan membutuhkan waktu dan sumber daya [10]. Menurut Soeharto [11] proyek diartikan sebagai kegiatan sementara yang berlangsung dalam waktu terbatas, dengan alokasi sumber daya tertentu dan bertujuan untuk menghasilkan produk dengan kriteria mutu tertentu. Suatu proyek harus memiliki tujuan khusus, misalnya pembangunan rumah/ jalan raya/ jembatan/ pabrik, penelitian dan pengembangan, pengembangan produk, pembangunan jaringan komunikasi, konservasi/ pelestarian lingkungan, dan lain sebagainya. Adapaun tiga batasan atau kendala yang harus dipenuhi dalam proses pencapaian tujuan proyek adalah anggaran biaya, jadwal, dan mutu. Penyelesaian proyek harus memenuhi batas maksimum anggaran yang ditentukan. Proyek juga harus dikerjakan sesuai dengan kurun waktu yang telah ditentukan. Mutu dari produk yang dihasilkan dari kegiatan proyek harus memenuhi ketentuan yang disyaratkan. Oleh karena itu, manajemen proyek sangat dibutuhkan dalam merencanakan, melaksanakan, dan mengendalikan proyek.

Penjadwalan proyek merupakan bagian dari tahap perencanaan proyek. Penjadwalan proyek merupakan kegiatan merencanakan waktu pengerjaan proyek mulai dari identifikasi jenis kegiatan, keterurutan, sampai kurun waktu (durasi) yang dibutuhkan setiap kegiatan. 
Beberapa faktor yang perlu diperhatikan dalam memperkirakan kurun waktu setiap kegiatan adalah sebagai berikut,

- Angka perkiraan bebas dari pengaruh kurun waktu kegiatan yang mendahului atau yang terjadi sesudahnya.

- Angka perkiraan kurun waktu kegiatan dihasilkan dari asumsi bahwa sumber daya tersedia dalam jumlah normal.

- Adanya kemungkinan untuk melaksanakan kegiatan secara paralel.

- Perhitungan hari kerja normal, tanpa asumsi lembur, kecuali pada kasus proyek khusus.

- Bebas dari pertimbangan mencapai target jadwal penyelesaian proyek, serta tidak memasukkan angka kontijensi untuk hal-hal seperti bencana alam (gempa bumi, banjir, badai), pemogokan, dan kebakaran.

Soeharto [11]

Perencanaan waktu berkaitan dengan perencanaan sumber daya dan biaya. Hasil dari perencanaan waktu memberikan informasi jumlah sumber daya dan biaya yang dibutuhkan dalam perencanaan proyek. Perencanaan waktu disusun seefisien mungkin agar proyek dapat diselesaikan sesuai dengan target waktu dan target biaya yang telah ditetapkan. Perencanaan waktu dalam penjadwalan proyek, dapat dianalisis dengan berbagai metode, baik metode deterministik seperti Critical Path Method (CPM), metode probabilistik seperti Program Evaluation and Review Technique (PERT), maupun metode metaheuristik seperti ant colony, algoritma genetika, dan cuckoo search.

\subsection{Penjadwalan Proyek dengan Biaya Harian}

Penjadwalan proyek dengan biaya harian merupakan perluasan dari metode penjadwalan proyek konvensional. Penjadwalan proyek yang hanya berorientasi mengoptimalkan waktu pengerjaan proyek, diperluas dengan menambahkan faktor penganggaran biaya harian. Biaya harian dikatakan optimal ketika rata-rata penyimpangan biaya harian terhadap rata-rata biaya perhari adalah minimal [5,9]. Optimasi waktu pengerjaan proyek dapat dikerjakan dengan metode CPM atau PERT. Dengan memanfaatkan total float (kelonggaran waktu) dari lintasan non kritis, penjadwalan dengan waktu yang optimal dapat diatur kembali dengan tanpa mempengaruhi kegiatan pada lintasan non kritis dan total waktu penyelesaian proyek yang optimal. Tujuan dari perlakuan ini adalah mendapatkan penyimpangan biaya harian seminimal mungkin dengan fungsi objektif,

$$
\text { Min } B=\frac{1}{T} \sum_{i=1}^{T}\left|b_{i}-\bar{b}\right|
$$

$\mathrm{B}$ adalah rata-rata penyimpangan biaya harian

T adalah waktu keseluruhan penjadwalan proyek

$b_{i}$ adalah biaya proyek pada hari ke-i (biaya harian proyek)

$\bar{b}$ adalah rata-rata biaya harian proyek

Biaya harian proyek dihitung berdasarkan jadwal proyek yang didapatkan dengan pengoptimalan waktu, dengan mengakumulasikan biaya kegiatan perhari dari kegiatankegiatan yang dilaksanakan pada hari yang sama, yaitu

$$
b_{i}=\sum_{i} \frac{b_{k i}}{T}
$$

dengan $b_{k i}$ merupakan biaya kegiatan yang dilaksanakan pada hari ke-i. Sedangkan rata-rata biaya harian proyek dihitung dengan membagi total biaya proyek dengan waktu keseluruhan penjadwalan proyek. Pengoptimalan biaya harian ini dapat dilakukan menggunakan metode- 
metode metaheuristik, seperti ant colony, genetic algorithm, dan cuckoo search. Metode tersebut tekenal handal dalam menyelesaikan berbagai masalah optimasi $[12,13,14,15,16]$.

\section{Metode}

Penelitian ini merupakan penelitian kuantitatif dengan studi kasus pada perusahaan properti di Kabupaten Tuban. Perusahaan tersebut memiliki 7 kawasan proyek perumahan dengan berbagai tipe. Penelitian ini merupakan penelitian awal, dimana penganggaran biaya yang dikaji adalah biaya harian. Penelitian difokuskan pada proyek pembangunan perumahan dua lantai tipe 65. Proyek terdiri dari 28 kegiatan dengan durasi single, dan logika keterdahuluan. Data diolah menggunakan metode CPM-CS [9] dengan fungsi fitnes seperti pada persamaan (1). Diagram alir penelitian ditunjukkan pada gambar 1. 


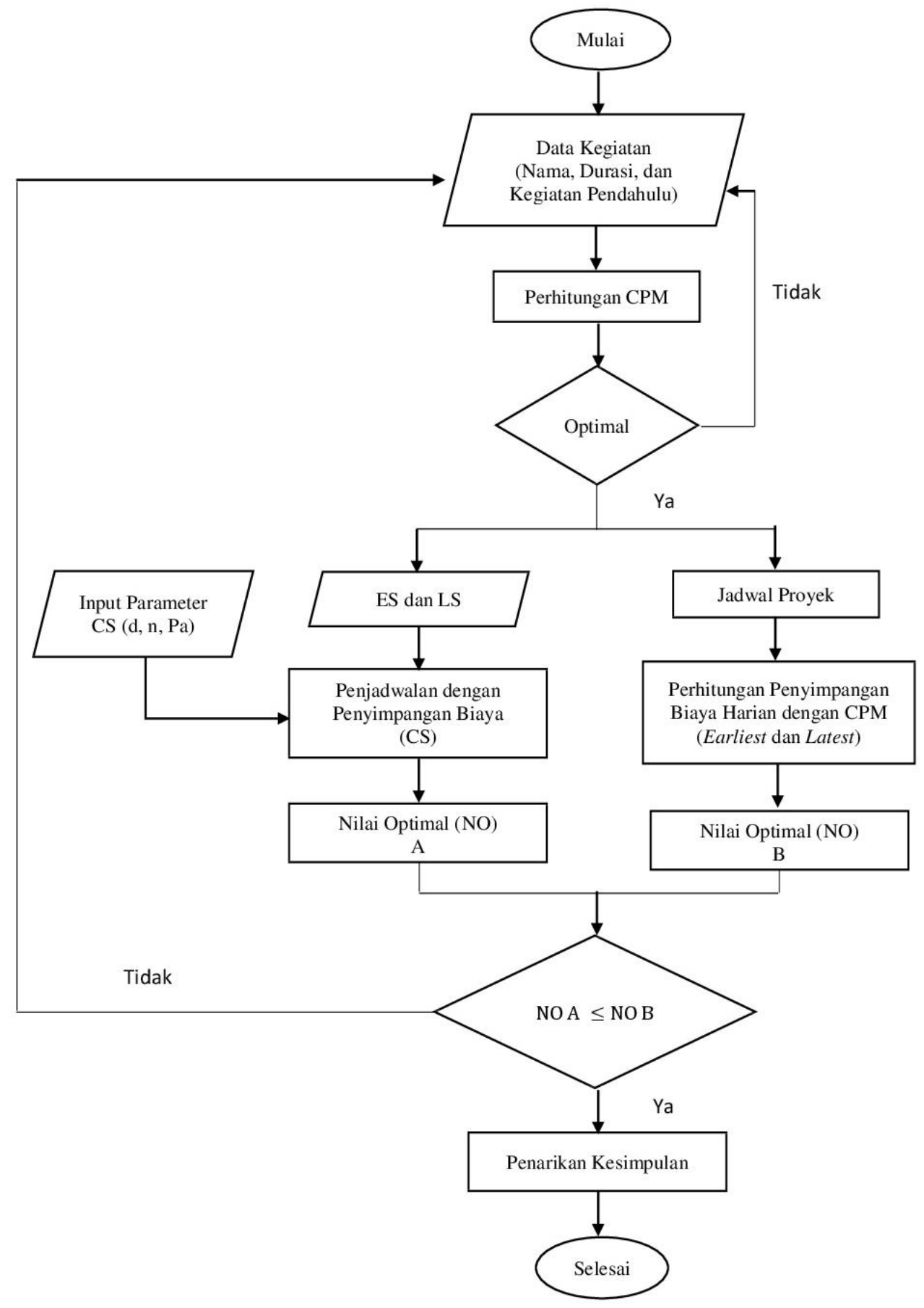

Gambar 1: Diagram Alir Penelitian

\section{Hasil dan Pembahasan}

Obyek dari penelitian ini adalah proyek pembangunan perumahan dua lantai tipe 65. Data kegiatan, durasi, dan kegiatan pendahulu proyek didapatkan dari hasil penelitian sebelumnya [2]. Terdapat 28 kegiatan dengan perubahan urutan simbol pada kegiatan L, M, dan N. Durasi yang digunakan pada penelitian ini adalah single duration dengan pembulatan ke atas. Sedangkan biaya proyek perkegiatan didapatkan dengan mengolah data Rencana Anggaran Biaya (RAB) dari hasil studi dokumen. Secara lengkap, data kegiatan, durasi, dan biaya proyek disajikan pada Tabel 1. 
Tabel 1: Kegiatan, Durasi, dan Biaya Proyek Perumahan Tipe 65

\begin{tabular}{|c|c|c|c|c|}
\hline $\begin{array}{c}\text { Simbol } \\
\text { Kegiatan }\end{array}$ & Uraian Kegiatan & $\begin{array}{c}\text { Durasi } \\
\text { (hari) }\end{array}$ & $\begin{array}{c}\text { Kegiatan } \\
\text { Pendahulu }\end{array}$ & $\begin{array}{c}\text { Biaya per Kegiatan } \\
(\text { Rp) }\end{array}$ \\
\hline $\mathrm{A}$ & Bouplank & 2 & - & 325000 \\
\hline $\mathrm{B}$ & Pondasi & 6 & $\mathrm{~A}$ & 17232320 \\
\hline $\mathrm{C}$ & Sloof & 8 & B & 6693750 \\
\hline $\mathrm{D}$ & Naik Bata & 19 & $\mathrm{C}, \mathrm{B}$ & 19725000 \\
\hline $\mathrm{E}$ & Instalasi Pipa Sanitair & 4 & $\mathrm{~B}$ & 7567780 \\
\hline $\mathrm{F}$ & Pasang Kusen lt.1 & 8 & $\mathrm{D}$ & 1440000 \\
\hline $\mathrm{G}$ & Pengerjaan dak lt.2 & 18 & $\mathrm{~F}$ & 39914305 \\
\hline $\mathrm{H}$ & Pengerjaan Tangga & 10 & $\mathrm{G}$ & 3031250 \\
\hline $\mathrm{I}$ & Pasang Bata lt.2 & 25 & $\mathrm{G}$ & 19725000 \\
\hline $\mathrm{J}$ & Pasang Kusen lt.2 & 6 & $\mathrm{G}$ & 2268000 \\
\hline $\mathrm{K}$ & Plester Aci & 30 & $\mathrm{H}$ & 52410290 \\
\hline $\mathrm{L}$ & Pasang Genteng & 2 & $\mathrm{H}$ & 4692500 \\
\hline $\mathrm{M}$ & Instalasi Jaringan Listrik & 3 & $\mathrm{~F}, \mathrm{I}, \mathrm{J}, \mathrm{K}, \mathrm{L}$ & 7290780 \\
\hline $\mathrm{N}$ & Naik Kuda Kuda lt.2 & 9 & M & 2991400 \\
\hline $\mathrm{O}$ & Pasang Kerpus & 5 & $\mathrm{M}$ & 5333350 \\
\hline $\mathrm{P}$ & Cat Dinding Luar & 18 & $\mathrm{~N}, \mathrm{O}$ & 1564360 \\
\hline Q & Pasang Plafon/Gypsum & 11 & $\mathrm{~N}, \mathrm{O}$ & 4324050 \\
\hline $\mathrm{R}$ & Pasang Keramik lt.1 & 21 & $\mathrm{Q}$ & 6577200 \\
\hline $\mathrm{S}$ & Pasang Keramik lt.2 & 20 & $Q$ & 6577200 \\
\hline $\mathrm{T}$ & Pengecatan Ruangan & 7 & $\mathrm{P}$ & 7438568 \\
\hline $\mathrm{U}$ & $\begin{array}{lll}\text { Pasang } & \text { Pintu } & \text { dan } \\
\text { Jendela } & & \end{array}$ & 13 & $\mathrm{~F}, \mathrm{~J}$ & 12602000 \\
\hline V & Nat Keramik & 3 & $\mathrm{R}, \mathrm{S}$ & 1414500 \\
\hline $\mathrm{W}$ & $\begin{array}{lll}\text { Melamin } & \text { Pintu } & \text { dan } \\
\text { Jendela }\end{array}$ & 16 & $\mathrm{~F}, \mathrm{~J}$ & 1554000 \\
\hline$X$ & Finishing Cat & 3 & $\mathrm{~T}$ & 1859642 \\
\hline $\mathrm{Y}$ & $\begin{array}{l}\text { Sanitair (Kran, Closed, } \\
\text { dll) }\end{array}$ & 8 & $\mathrm{U}, \mathrm{V}, \mathrm{W}, \mathrm{X}$ & 2260000 \\
\hline $\mathrm{Z}$ & Meteran Listrik & 2 & $\mathrm{U}, \mathrm{V}, \mathrm{W}, \mathrm{X}$ & 2000000 \\
\hline AA & Taman & 15 & $\mathrm{Y}, \mathrm{Z}$ & 2898470 \\
\hline $\mathrm{AB}$ & Pembersihan & 3 & AA & 250000 \\
\hline
\end{tabular}

Waktu paling cepat dimulainya kegiatan (ES), waktu paling cepat selesainya kegiatan (EF), waktu paling lambat dimulainya kegiatan (LS), dan waktu paling lambat selesainya kegiatan (LF) dihitung menggunakan metode CPM dengan bantuan aplikasi POM QM for windows. Hasil perhitungan ES, EF, LS, dan LF disajikan pada Tabel 2, dengan total waktu pengerjaan proyek selama 174 hari.

Kegiatan A-D, F-H, K, M, N, Q, R, V, Y, AA, dan AB berada pada lintasan kritis. Ini berarti bahwa pelaksanaan kegiatan-kegiatan tersebut harus tepat waktu (tidak dapat ditunda). Sedangkan kegiatan E, I, J, L, O, P, S-U, W, X, dan Z berada pada lintasan non kritis dengan total float (kelonggaran waktu) bernilai positif. Ini berarti bahwa pelaksanaan kegiatan-kegiatan tersebut dapat ditunda sesuai dengan kelonggaran waktu yang ada. Dengan memanfaatkan total float pada kegiatan-kegiatan non kritis, jadwal dapat diatur ulang untuk mengoptimasi biaya harian tanpa merubah waktu keseluruhan pengerjaan proyek yang telah dioptimasi. 
Tabel 2: ES, EF, LS, dan LF Proyek Perumahan Tipe 65

\begin{tabular}{|c|c|c|c|c|c|c|}
\hline \multirow{2}{*}{$\begin{array}{c}\text { Simbol } \\
\text { Kegiatan }\end{array}$} & \multicolumn{2}{|c|}{ Waktu Paling Cepat } & \multicolumn{2}{|c|}{ Waktu Paling Lambat } & \multirow{2}{*}{$\begin{array}{c}\text { Total } \\
\text { Float } \\
\text { (LS-ES) }\end{array}$} & \multirow[b]{2}{*}{ Ket. } \\
\hline & $\begin{array}{c}\text { Mulai } \\
\text { (ES) }\end{array}$ & $\begin{array}{c}\text { Selesai } \\
\text { (EF) }\end{array}$ & $\begin{array}{l}\text { Mulai } \\
\text { (LS) }\end{array}$ & $\begin{array}{c}\text { Selesai } \\
\text { (LF) }\end{array}$ & & \\
\hline $\mathrm{A}$ & 0 & 2 & 0 & 2 & 0 & Kritis \\
\hline $\mathrm{B}$ & 2 & 8 & 2 & 8 & 0 & Kritis \\
\hline $\mathrm{C}$ & 8 & 16 & 8 & 16 & 0 & Kritis \\
\hline $\mathrm{D}$ & 16 & 35 & 16 & 35 & 0 & Kritis \\
\hline E & 8 & 12 & 170 & 174 & 162 & $\begin{array}{c}\text { Non } \\
\text { Kritis }\end{array}$ \\
\hline $\mathrm{F}$ & 35 & 43 & 35 & 43 & 0 & Kritis \\
\hline $\mathrm{G}$ & 43 & 61 & 43 & 61 & 0 & Kritis \\
\hline $\mathrm{H}$ & 61 & 71 & 61 & 71 & 0 & Kritis \\
\hline I & 61 & 86 & 76 & 101 & 15 & $\begin{array}{c}\text { Non } \\
\text { Kritis }\end{array}$ \\
\hline $\mathrm{J}$ & 61 & 67 & 95 & 101 & 34 & $\begin{array}{c}\text { Non } \\
\text { Kritis }\end{array}$ \\
\hline $\mathrm{K}$ & 71 & 101 & 71 & 101 & 0 & Kritis \\
\hline $\mathrm{L}$ & 71 & 73 & 99 & 101 & 28 & $\begin{array}{c}\text { Non } \\
\text { Kritis }\end{array}$ \\
\hline $\mathrm{M}$ & 101 & 104 & 101 & 104 & 0 & Kritis \\
\hline $\mathrm{N}$ & 104 & 113 & 104 & 113 & 0 & Kritis \\
\hline $\mathrm{O}$ & 104 & 109 & 108 & 113 & 4 & $\begin{array}{c}\text { Non } \\
\text { Kritis }\end{array}$ \\
\hline $\mathrm{P}$ & 113 & 131 & 120 & 138 & 7 & $\begin{array}{c}\text { Non } \\
\text { Kritis }\end{array}$ \\
\hline Q & 113 & 124 & 113 & 124 & 0 & Kritis \\
\hline $\mathrm{R}$ & 124 & 145 & 124 & 145 & 0 & Kritis \\
\hline S & 124 & 144 & 125 & 145 & 1 & $\begin{array}{c}\text { Non } \\
\text { Kritis }\end{array}$ \\
\hline $\mathrm{T}$ & 131 & 138 & 138 & 145 & 7 & $\begin{array}{c}\text { Non } \\
\text { Kritis }\end{array}$ \\
\hline $\mathrm{U}$ & 67 & 80 & 135 & 148 & 68 & $\begin{array}{c}\text { Non } \\
\text { Kritis }\end{array}$ \\
\hline $\mathrm{V}$ & 145 & 148 & 145 & 148 & 0 & Kritis \\
\hline W & 67 & 83 & 132 & 148 & 65 & $\begin{array}{c}\text { Non } \\
\text { Kritis }\end{array}$ \\
\hline$X$ & 138 & 141 & 145 & 148 & 7 & $\begin{array}{c}\text { Non } \\
\text { Kritis }\end{array}$ \\
\hline $\mathrm{Y}$ & 148 & 156 & 148 & 156 & 0 & Kritis \\
\hline Z & 148 & 150 & 154 & 156 & 6 & $\begin{array}{c}\text { Non } \\
\text { Kritis }\end{array}$ \\
\hline AA & 156 & 171 & 156 & 171 & 0 & Kritis \\
\hline $\mathrm{AB}$ & 171 & 174 & 171 & 174 & 0 & Kritis \\
\hline
\end{tabular}

Jadwal proyek untuk perhitungan waktu paling cepat (Earliest) dan waktu paling lambat (Latest) dapat dilihat pada Gambar 2 dan Gambar 3. Berdasarkan jadwal tersebut dihitung biaya kegiatan perhari dengan persamaan (2) dan didapatkan rata-rata biaya perhari sebesar Rp.1.390.579,-, rata-rata penyimpangan biaya perhari untuk perhitungan Earliest sebesar Rp.863.739,- dan rata-rata penyimpangan biaya perhari untuk perhitungan Latest sebesar Rp.918.878,-. 


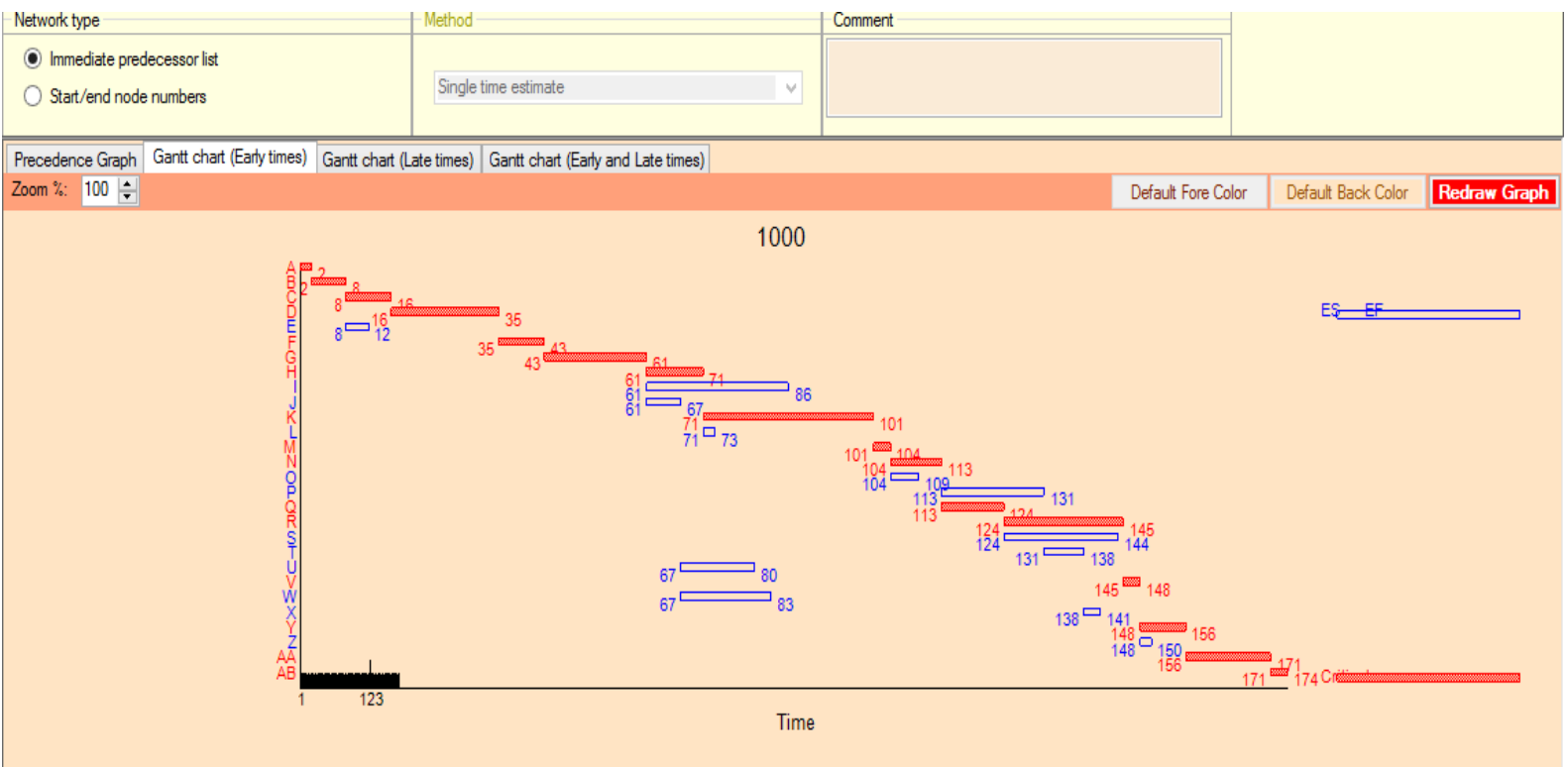

Gambar 2: Jadwal Proyek Perumahan dengan Metode CPM untuk Perhitungan Earliest

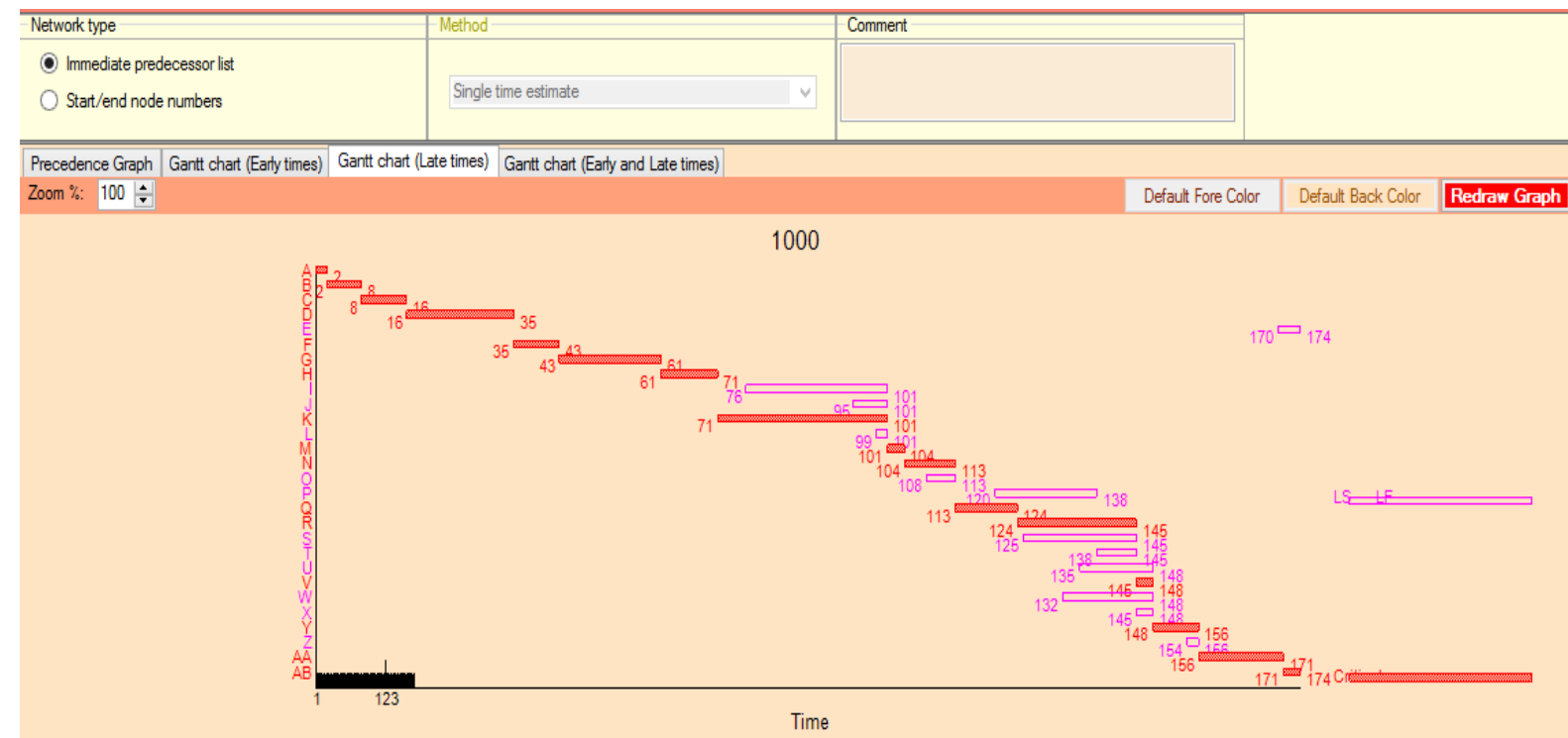

Gambar 3: Jadwal Proyek Perumahan dengan Metode CPM untuk Perhitungan Latest

Selanjutnya, data diolah dengan metode CPM-CS. Dalam hal ini, nilai ES dan LS pada perhitungan CPM digunakan sebagai input batas bawah dan batas atas waktu pengerjaan proyek pada algoritma CS. Setelah dijalankan sebanyak 20 kali, dengan input parameter, $d=28, n=10 d$, $\mathrm{pa}=0,25$, dan iterasi maksimum $=50000$, didapatkan rata-rata penyimpangan biaya perhari sebesar Rp. 712.510,-. Perbandingan waktu dimulainya kegiatan dengan metode CPM (Earliest), CPM (Latest), dan CPM-CS disajikan pada Tabel 3. Perbandingan nilai optimal untuk ketiga metode tersebut disajikan pada tabel 4. 
Tabel 3: Perbandingan Waktu Mulai Kegiatan

\begin{tabular}{|c|c|c|c|}
\hline \multirow{2}{*}{ Simbol Kegiatan } & \multicolumn{3}{|c|}{ CPM-CS } \\
\cline { 2 - 4 } & CPM (Earliest) & CPM (Latest) & CPM-CS \\
\hline A & 1 & 1 & 1 \\
\hline B & 3 & 3 & 3 \\
\hline C & 9 & 9 & 9 \\
\hline D & 17 & 17 & 17 \\
\hline E & 9 & 171 & 170 \\
\hline F & 36 & 36 & 36 \\
\hline G & 44 & 44 & 44 \\
\hline H & 62 & 62 & 62 \\
\hline I & 62 & 77 & 63 \\
\hline J & 62 & 96 & 65 \\
\hline K & 72 & 72 & 72 \\
\hline L & 72 & 100 & 74 \\
\hline M & 102 & 102 & 102 \\
\hline N & 105 & 105 & 105 \\
\hline O & 105 & 109 & 106 \\
\hline P & 114 & 121 & 118 \\
\hline Q & 114 & 114 & 114 \\
\hline R & 125 & 125 & 125 \\
\hline S & 125 & 126 & 125 \\
\hline T & 132 & 139 & 138 \\
\hline U & 68 & 136 & 111 \\
\hline V & 146 & 146 & 146 \\
\hline W & 68 & 133 & 70 \\
\hline X & 139 & 146 & 145 \\
\hline Y & 149 & 149 & 149 \\
\hline Z & 149 & 155 & 155 \\
\hline AA & 157 & 157 & 157 \\
\hline AB & 172 & 172 & 172 \\
\hline & & & \\
\hline
\end{tabular}

Tabel 4: Perbandingan Nilai Optimum dalam Penjadwalan Proyek

\begin{tabular}{|c|c|}
\hline Metode & Nilai Optimum \\
\hline CPM $($ Earliest $)$ & 863739 \\
\hline CPM $($ Latest $)$ & 918878 \\
\hline CPM-CS & 712510 \\
\hline
\end{tabular}

Tabel 3 menunjukkan waktu dimulainya kegiatan proyek, sedangkan waktu selesainya kegiatan disesuaikan dengan durasinya. Sebagai contoh, kegiatan A dimulai pada hari ke-1 dan selesai pada hari ke-2. Berikutnya kegiatan B dimulai pada hari ke-3 dan selesai pada hari ke8, dan seterusnya. Pada Tabel 3 terlihat bahwa kegiatan-kegiatan pada lintasan kritis dimulai pada hari yang sama untuk ketiga metode, sedangkan kegiatan-kegiatan pada lintasan non kritis (daerah yang diarsir) dimulai pada hari yang bervariasi dengan memanfaatkan kelonggaran waktu. CPM (Earliest dan latest) mengoptimalkan waktu pengerjaan proyek tanpa memperhatikan penyimpangan biaya harian, sedangkan CPM-CS mengoptimalkan waktu sekaligus biaya harian. Tabel 4 menunjukkan bahwa CPM-CS lebih optimal daripada CPM 
(Earliest) dan CPM (latest). Gambar 4 menunjukkan perbandingan penggunaan biaya harian terhadap rata-ratanya dengan perhitungan menggunakan ketiga metode. Penyimpangan terbesar menggunakan metode CPM (Earliest) terjadi pada hari ke-72, CPM (Latest) terjadi pada hari ke-100, dan CPM-CS terjadi pada hari ke-76. Secara keseluruhan, rata-rata penyimpangan biaya harian dengan CPM-CS lebih optimal daripada CPM (Earliest) dan CPM (latest).

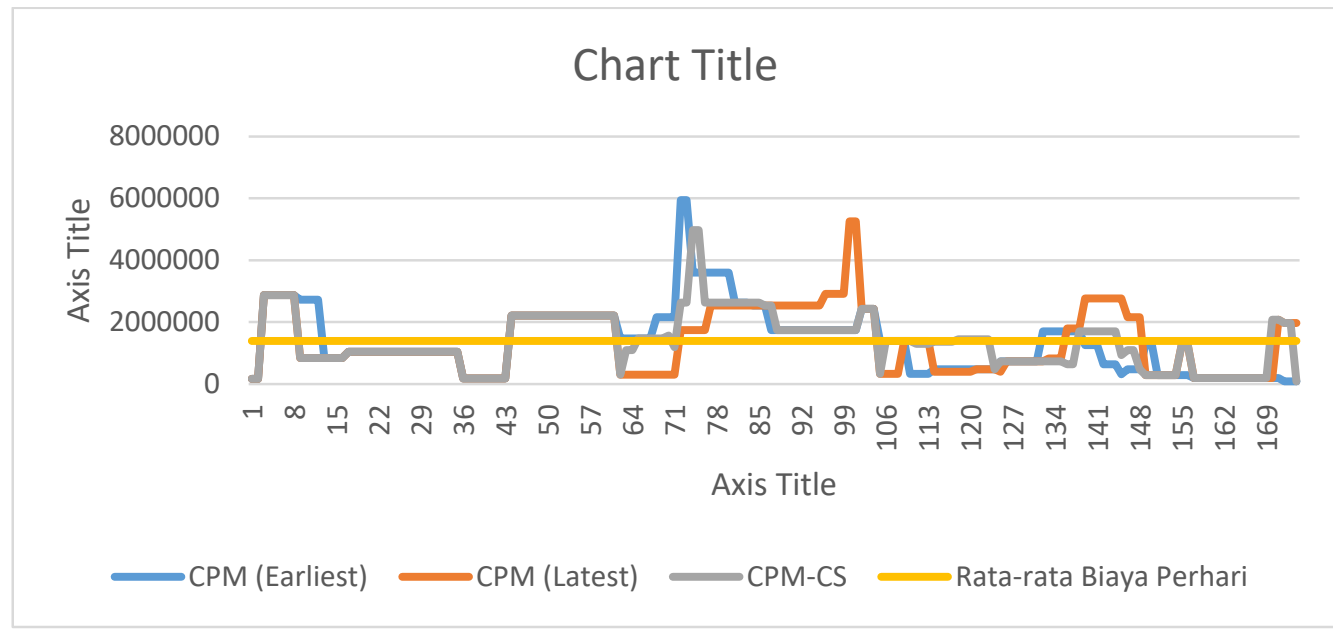

Gambar 4: Grafik Perbandingan Penggunaan Biaya Harian CPM (Earliest), CPM (Latest), dan CPM-CS

Berdasarkan hasil perhitungan dengan metode CPM (Earliest), CPM (latest), dan CPMCS , proyek perumahan dapat diselesaikan secara optimal dalam kurun waktu 174 hari, dengan 3 alternatif penjadwalan proyek seperti pada Tabel 3. Dengan memanfaatkan kelonggaran waktu, CPM-CS dapat menyusun kembali jadwal proyek, untuk mendapatkan rata-rata penyimpangan biaya harian yang minimal tanpa merubah keoptimalan waktu. Sehingga, penjadwalan proyek perumahan dengan CPM-CS lebih optimal daripada CPM (Earliest) dan CPM (latest).

\section{Kesimpulan}

Penjadwalan proyek perumahan dapat dibuat realistis sesuai keadaan dilapangan dengan menambahkan faktor biaya harian dalam perhitungan optimasi. CPM-CS dapat diaplikasikan pada masalah penjadwalan proyek perumahan dengan mengoptimalkan waktu dan biaya harian. CPM-CS memberikan jadwal proyek dengan rata-rata penyimpangan biaya harian yang lebih optimal daripada CPM (Earliest) dan CPM (latest).

Penelitian ini masih terbatas pada penambahan faktor biaya harian. Pada kenyataannya, pembiayaan proyek diberikan oleh pengembang kepada kontraktor sesuai dengan perjanjian, secara bertahap berdasarkan pada perkembangan pembangunan. Penelitian selanjutnya diharapkan mempertimbangkan sistem pembiayaan proyek secara bertahap sesuai perkembangan pembangunan, mempertimbangkan biaya tenaga kerja, serta menambahkan faktor-faktor lain yang berpengaruh.

\section{Ucapan Terima Kasih}

Ucapan terima kasih peneliti ucapkan kepada Lembaga Penelitian Universitas PGRI Ronggolawe Tuban atas Hibah Penelitian DIPA Unirow Tuban Tahun Anggaran 2019 


\section{Daftar Pustaka}

[1] F. F. Farlianto, "Studi Faktor-Faktor Keterlambatan Proyek pada Kontraktor di Daerah Istimewa Yogyakarta", Jurnal Ilmu Manajemen, vol. 12, no. 2, pp. 10-27, 2015.

[2] S. R. Jannah, L. Muzdalifah, dan E. F. Kurniawati, "Optimasi Waktu Penjadwalan Proyek Pembangunan Perumahan Menggunakan Critical Path Method (CPM)/ Program Evaluation and Review Technique (PERT) dan Simulasi Monte Carlo (Studi Kasus CV. Granada Property)", Prosiding Seminar Nasional Hasil Penelitian dan Pengabdian kepada Masyarakat III, 461-465. Universitas PGRI Ronggolawe Tuban, September, 2018.

[3] E. R. M. Iwawo, J. Tjakra, P. A. K. Pratasis, "Penerapan Metode CPM Pada Proyek Konstruksi (Studi Kasus Pembangunan Gedung Baru Kompleks Eben Haezar Manado)", Jurnal Sipil Statik, vol. 4, no. 9, pp. 551-558, 2016.

[4] I. A. Suherman, "Analisa Penjadwalan Proyek Menggunakan PDM dan PERT serta Crash Project", Jurnal Teknik Industri: Jurnal Hasil Penelitian dan Karya Ilmiah dalam Bidang Teknik Industri, vol. 2, no. 1, pp. 31-43, 2016.

[5] R. Arifudin, "Optimasi Penjadwalan Proyek dengan Pernyeimbangan Biaya Menggunakan Kombinasi CPM dan Algoritma Genetika", Jurnal Masyarakat Informatika, vol. 2, no. 4, pp. 1-14, 2011.

[6] Junaidi, "Pengendalian Waktu dan Biaya pada Tahap Pelaksanaan Proyek dengan Menggunakan Metode Nilai Hasil (Studi Kasus: Proyek Lanjutan Pembangunan Gedung PIP2B Kota Manado)", Jurnal Sipil Statik, vol. 1, no. 1, pp. 44-52, 2012.

[7] Y. Andriani dan Nurfatwa, "Sistem Informasi Penjadwalan Proyek Performansi Biaya pada PT. Kelana Buana Sulawesi Selatan", Jurnal INSTEK, vol. 2, no. 2, pp. 61-70, 2017.

[8] Sediyanto dan A. Hidayat, “ Analisis Kinerja Biaya dan Waktu pada Pelaksanaan Proyek Konstruksi dengan Metode Earned Value (Studi Kasus Proyek Konstruksi Mall dan Hotel X di Pekanbaru)", Jurnal Ilmu Teknik dan Komputer, vol. 1, no. 1, pp. 36-51, 2017.

[9] L. Muzdalifah dan E. F. Kurniawati, “CPM-CS untuk Optimasi Penjadwalan Proyek”, Prosiding Seminar Nasional Hasil Penelitian dan Pengabdian kepada Masyarakat IV. Universitas PGRI Ronggolawe Tuban, September, 2019.

[10] H. A. Taha. Operations Research: An Introduction, Eighth Edition, New Jersey: Pearson Education, Inc, 2007.

[11] I. Soeharto, Manajemen Proyek (dari Konseptual sampai Operasional), Edisi Kedua, Jilid 1, Jakarta: Erlangga, 1999.

[12] A. Zarman, M. Irfan, dan W. Uriawan, "Implementasi Algoritma Ant Colony Optimization pada Aplikasi Pencarian Lokasi Tempat Ibadah Terdekat di Kota Bandung", JurnalOnline Informatika, vol. I, no. 1, pp. 6-12, 2016.

[13] B. P. Jocom, N. Hidayat, dan P. P. Adikara, "Penerapan Genetic Algorithm untuk Optimasi Peningkatan Laba Persediaan Produksi Pakaian", Jurnal Pengembangan Teknologi Informasi dan Ilmu Komputer, vol. 2, no. 6, pp. 2168-2172, 2018.

[14] L. Muzdalifah, "Binary Cuckoo Search untuk Optimasi Portofolio dengan Kendala Cardinality", Jurnal AdmathEdu, vol. 6, no.1, pp. 25-32, 2016.

[15] L. Muzdalifah, "Binary Cuckoo Search Untuk Masalah Optimasi Diskrit", Prosiding Seminar Nasional Matematika dan Pembelajarannya, pp. 1229-1233. Universitas Negeri Malang, Agustus, 2016.

[16] L. Muzdalifah, "Optimasi Portofolio dengan Kendala Buy-In Threshold menggunakan Metode Cuckoo Search", Jurnal Riset dan aplikasi Matematika, vol. 2, no.1, pp. 13-22, 2018. 